\title{
Financeirização do imobiliário no Brasil: uma análise dos Certificados de Recebíveis Imobiliários (2005-2020)
}

\author{
Financialization of real estate in Brazil: an analysis \\ of Real Estate Receivables Certificates (2005-2020)
}

\author{
Ramon da Silva Torres [I] \\ João Bosco Moura Tonucci Filho [II] \\ Renan Pereira Almeida [III]
}

\section{Resumo}

Este artigo busca compreender os contornos do processo de financeirização do imobiliário no Brasil sob a centralidade das operações de securitização, criadas no sentido de conectar o mercado imobiliário ao mercado de capitais. A análise fundamenta-se em uma amostra de dados sobre os Certificados de Recebíveis Imobiliários (CRI) emitidos entre 2005-2020, priorizando o mapeamento dos interesses e das interações entre os agentes envolvidos na cessão de créditos imobiliários. Constatou-se a baixa capacidade dos CRIs (e outros instrumentos) de financiar a habitação. Contudo, eles têm cumprido um papel fundamental para o setor financeiro: a aceleração do ciclo de reprodução do capital no setor imobiliário e a absorção crescente da riqueza imobiliária sob gestão dos fundos de investimento.

Palavras-chave: financeirização; crédito habitacional; sistema financeiro imobiliário; fundos de investimento imobiliário; securitização.

\begin{abstract}
This work seeks to understand the financialization process of real estate in Brazil focusing on securitization operations, created in order to connect the real estate market to the capital market. The analysis is based on a sample of data on Real Estate Receivables Certificates (CRI) issued between 2005 and 2020, mapping the interests and interactions between agents involved in the assignment of real estate credits. It shows the limited capacity of CRI (and other instruments) for housing finance. Nevertheless, it has played a fundamental role for the financial sector: the acceleration of the capital reproduction cycle in the real estate sector and the absorption of real estate wealth under investment funds.
\end{abstract}

Keywords: financialization; housing credit; real estate finance; real estate investment trusts; securitization. 


\section{Introdução}

A eclosão da crise econômica global de 20072009 evidenciou os nexos entre mercados imobiliários, urbanização e financeirização, esta última entendida como o domínio crescente de atores, mercados, práticas e narrativas financeiras em várias esferas da sociedade (Aalbers, 2017) ou como a hegemonia do capital fictício no capitalismo contemporâneo (Harvey, 2006). Entre as grandes transformações contemporâneas do capitalismo (Bógus e Ribeiro, 2018), reconhece-se cada vez mais a terra (urbana) como principal fonte de "rendas" em economias avançadas (Ryan-Collins et al., 2017). Isso se expressa no aumento substantivo do estoque de riqueza representada por habitação desde os anos 1980, vis-à-vis a perda de peso da riqueza em capital (Piketty, 2014). Isso também se reflete no fato de que os empréstimos hipotecários constituem hoje a principal fonte de crédito nas economias centrais, superando os financiamentos produtivos da economia "real" (bens de capital, inovação, etc.) (Jordà et al., 2014).

Nos países centrais, a financeirização do imobiliário opera por múltiplos canais que se reforçam mutuamente. Entre eles, cabe destacar: a ascensão da hegemonia da casa própria em detrimento de outras formas de moradia, a expansão do crédito hipotecário em um contexto de salários reais declinantes, a inclusão de consumidores de baixa renda e maior risco no sistema bancário, a crescente influência de novos atores financeiros (como fundos de investimento e de pensão), a globalização dos mercados financeiros e, principalmente, a criação de mercados secundários de hipotecas via securitização (Aalbers, 2008; Rolnik, 2015).
Já, no Brasil, a financeirização do imobiliário é um processo que teve seu marco inicial mais tardiamente, com a criação do Sistema Financeiro Imobiliário (SFI) em 1997. Apesar de o SFI existir há mais de duas décadas, seus instrumentos e as regulações propostas exigiram um período de maturação e ajustes (Sanfelici e Halbert, 2018), até que os dispositivos criados pudessem vir a sustentar uma estrutura de funding paralela ao Sistema Financeiro da Habitação (SFH), principal sistema de financiamento imobiliário até hoje. Durante as duas últimas décadas, a literatura nacional em torno do tema trabalhou com dois principais focos: 0 processo de abertura de capital das construtoras em meados dos anos 2000 (Shimbo, 2010; Fix, 2011; Sanfelici, 2013) e a evolução da configuração do circuito financeiro imobiliário baseado nas interações entre SFH e SFI (Royer, 2009; Fix, 2011; Pereira, 2015).

O fenômeno da securitização no Brasil é ainda mais recente. A versão brasileira dos Mortgage Backed Securities (MBS) são os Certificados de Recebíveis Imobiliários (CRIs) instituídos em 1997 através da mesma lei que criou o Sistema Financeiro Imobiliário. Essas operações, contudo, só se desenvolveram a partir do reforço à segurança jurídica dos credores, com a inclusão do regime de alienação fiduciária no Código Civil pela lei n. 10.931 de 2004 (Pereira, 2015). Além disso, o FGTS desempenhou o papel de impulsionamento desse mercado através da compra significativa de CRIs emitidos entre 2011-2016 (Royer, 2016; Abreu, 2019). A partir de 2016, entretanto, o vácuo deixado pelo FGTS na compra de CRI tem sido preenchido por investidores pessoa física e fundos de investimento, particularmente os Fundos de Investimento Imobiliário (FII). Este último apresentou um crescimento expressivo nos 
últimos três anos, acompanhando o movimento da queda da taxa de juros em níveis inéditos para a economia nacional.

Essas alterações recentes nos agentes financiadores da securitização levantam suspeitas sobre mudanças no objeto imobiliário que está sendo securitizado. Este estudo, por meio de um mapeamento amplo dos agentes envolvidos na securitização imobiliária (financiadores, cedentes de crédito, coordenadores de emissões), busca compreender quais os papéis desempenhados por esses agentes e como ele se beneficiam desse processo, ressaltando as similaridades e as distinções com o que é abordado pela literatura internacional sobre a financeirização. Para isso, utiliza-se a base de dados da Anbima (Associação Brasileira das Entidades dos Mercados Financeiro e de Capitais) sobre as emissões de CRIs no período de 2005-2020. Trata-se de uma amostra com cobertura de $81 \%$ de todas as operações do período. A análise dos agentes está fundamentada na categorização dos cedentes do crédito imobiliário em grupos de empresas com atividade econômica similar (Bancos, Flls, Empresas Imobiliárias), buscando compreender as razões por trás da transformação da renda imobiliária em títulos financeiros que possam ser negociados no mercado de capitais. Complementarmente, foram utilizadas outras fontes de dados da Anbima e as atas do Conselho Curador do FGTS (CCFGTS).

A securitização imobiliária ainda é uma temática recente dentro dos estudos sobre financeirização no País, na medida em que a literatura nacional que aborda especificamente os Flls e os CRIs permanece escassa e que esses temas tendem a ser tratados marginalmente quando se discute a estruturação do SFI. ${ }^{1}$ Um dos fatores que explicam o baixo número de estudos sobre o tema pode ser o fato de que esses instrumentos não alteraram significativamente o quadro geral do circuito financeiro imobiliário no País, ainda bastante centrado nos recursos do FGTS e do SBPE (Pereira, 2015). Contudo, devido à tendência estrutural de tratamento da terra enquanto um ativo financeiro puro (Harvey, 2006) e à importância da securitização enquanto pedra angular de um processo de financeirização em escala global, o presente trabalho procura compreender como essa vertente da financeirização tem se comportado no Brasil.

Desse modo, o artigo divide-se em 6 seções, incluindo esta breve introdução. $\mathrm{Na}$ seção 2, apresenta-se uma sucinta revisão bibliográfica sobre o tema da financeirização do imobiliário no mundo e no Brasil, com foco na securitização. Na seção 3, descrevem-se os elementos que compõem o SFI e seus principais instrumentos. Na seção 4 , apresentam-se as bases de dados utilizadas, o método desenvolvido para analisá-las e uma breve análise exploratória. A seção 5 analisa os agentes envolvidos na securitização imobiliária. A seção 6 apresenta as conclusões e traz comentários acerca da evolução recente do financiamento imobiliário no País que poderão ser investigados em pesquisas futuras.

\section{Financeirização do imobiliário e securitização em perspectiva}

Em termos teóricos, a financeirização do imobiliário pode ser entendida como a manifestação de uma tendência secular e estrutural do capitalismo, conforme explicitada por Harvey (2006): o tratamento da terra enquanto um 
ativo financeiro puro. Essa tendência se apresenta como um processo multifacetado. A terra e particularmente a moradia mostram-se objetos preferenciais de financeirização por suas propriedades específicas (imobilidade, durabilidade, irreprodutibilidade), que a tornam um excelente colateral e investimento (Ryan-Collins, Lloyd e MacFarlane, 2017). Como apontam Loftus et al. (2018), ativos que proveem fluxos de rendas estáveis, protegidos da inflação, e regulados, são particularmente relevantes para os rentistas financeiros.

Dentre as políticas que criaram as condições para a financeirização do imobiliário nos países centrais, particularmente a partir da década de 1980, destacam-se a desregulamentação e abertura bancária/financeira, a desconstrução de políticas habitacionais, a adoção de políticas voltadas ao mercado e comprometidas com a maximização da renda da terra (Harvey, 2007; Rolnik, 2015). Diversos são os canais de fluxo de extração de mais-valor criados pelos mercados financeiros de forma a se apropriar e rentabilizar o ambiente construído urbano (Tonucci e Magalhães, 2017). Parcerias Público-Privadas (PPP), títulos que conferem direitos de potencial construtivo adicional, operações de securitização imobiliária, abertura de capital de incorporadoras e fundos de investimento específicos ao mercado imobiliário têm, conjuntamente, aberto novas frentes de acumulação para o capital financeiro, que, por sua vez, revela um forte traço rentista sob o capitalismo contemporâneo (Paulani, 2016). A securitização é uma operação em que uma empresa que possui contratos imobiliários, como aluguéis, contratos de compra e venda, financiamentos imobiliários, arrendamento e cessão de superfície, pode ceder seu direito de receber as rendas futuras desses contratos em troca de um valor presente. Nesse sentido, transforma um bem imóvel e suas características intrínsecas em um direito de rendas futuras incorporado em um título a ser negociado no mercado financeiro (Melazzo e Abreu, 2019). Em outras palavras, um proprietário abre mão de receber aluguéis ao longo do tempo em troca de um valor correspondente a esses aluguéis hoje. 0 comprador desse título dispõe de dinheiro hoje e troca esse dinheiro pelo direito de receber o fluxo de aluguéis futuros e/ou a valorização desse título.

A securitização permitiu, ao capital, superar as barreiras impostas pelo espaço ao processo de acumulação, tais como a imobilidade da propriedade imobiliária, seu longo período de maturação e os altos custos de transação (Gotham, 2012). A transformação deu-se no sentido de criar mercadorias novas, os títulos financeiros atrelados às dívidas imobiliárias, facilmente transacionáveis em escala global, com previsão de retorno e marketability, ou seja, desejáveis pelos investidores (ibid.). Ao conectar os mercados imobiliários locais com a estrutura de funding global, a securitização facilitou ainda o deslocamento do excedente de capital para a construção de novas paisagens geográficas (Harvey, 2012).

Estudos recentes, assentados em bases de dados de longo prazo (i.e., desde 1870) do sistema bancário para um conjunto de 17 economias dos principais países desenvolvidos, têm constatado uma tendência secular e com importantes consequências para a dinâmica dos ciclos econômicos e urbanos: o crescimento do crédito imobiliário em relação ao crédito não imobiliário. Atualmente, cerca de dois terços do crédito bancário nessas economias são direcionados para compra de imóveis, fazendo com que o crédito hipotecário no balanço dos 
bancos seja a principal força por trás de um processo de financeirização das economias centrais (Jordà et al., 2014). Um dos fatores relacionados à expansão do crédito imobiliário tem sido a consolidação e a ampliação das operações de securitização imobiliária, o que permitiu aos bancos retirar os créditos imobiliários de seus balanços, repassando-os ao mercado de capitais por meio de títulos de recebíveis imobiliários, ampliando, assim, a capacidade para concessão de novos empréstimos (Gotham, 2012).

A securitização possibilitou, ainda, uma mudança no modelo de negócios das instituições financeiras. Através da comercialização dos financiamentos imobiliários em seus balanços, os bancos terceirizaram o risco das operações de crédito para os compradores dos títulos e passaram a rentabilizar a concessão de financiamento imobiliário através mais da cobrança de taxas sobre a comercialização de operações de securitização do que sobre a cobrança dos juros. Esse modelo propiciou, aos bancos, elevar a lucratividade sem a necessidade de aumentar o risco de suas atividades (Crotty, 2008; Dymski, 2009).

0 formato moderno da securitização emerge nos Estados Unidos (EUA) por volta dos anos 1930, momento em que o Estado efetivamente entra no mercado de hipotecas. Posteriormente, através de agências patrocinadas pelo Estado, irá integrar os mortgage markets pelo território americano em um único mercado. A padronização dessas operações configurou liquidez a esses ativos em escala nacional, amadurecendo o mercado primário de títulos e abrindo a possibilidade para um mercado secundário global. 0 papel ativo do Estado americano, não só na institucionalização desse mercado, mas em seu impulsionamento através da concessão de garantias para as operações de securitização no mercado secundário, levou os EUA a possuírem o mais expressivo mercado desses títulos no mundo. Na Europa, a securitização é mais recente e o apoio governamental é mais limitado. Contudo, vem crescendo o volume de hipotecas securitizadas, e um mercado secundário desses títulos tem se firmado, sobretudo, no Reino Unido, Espanha, Países Baixos, Itália e, em menor medida, na Alemanha, França e Portugal (Aalbers, 2008).

No Brasil, apesar de observadas algumas tendências identificadas pela literatura internacional nas economias avançadas, a financeirização permanece de alguma forma limitada, devido às contingências locais. Segundo Pereira (2017), entre as razões que diferem o Brasil das economias centrais estão: 1) o acesso à moradia nunca foi universal no País; e 2) o nível de liquidez global desempenha um papel distinto nas economias periféricas, mais relacionado à procura por investimentos de elevado retorno do que a uma procura por investimentos de baixo risco, tais como os HQC. Este último fator se deve, em partes, às altas taxas de juros praticadas em economias periféricas, em particular no Brasil.

Mesmo que limitado e contingenciado, há evidências de um processo de financeirização do imobiliário em curso no País. Se, em um primeiro momento, do ponto de vista da estruturação do SFI e seus instrumentos, a securitização esteve em boa parte sustentada por um fundo público, agora, o FGTS parece emergir enquanto um fenômeno mais genuinamente de mercado, pulverizado entre uma miríade de agentes. Isso revela um outro vetor de crescimento dessas operações e um aprofundamento da conexão entre o mercado 
imobiliário e o mercado de capitais. Essa conexão se torna possível somente através da abertura de novos canais de fluxos de mais-valor, a partir da criação de dispositivos e instrumentos que permitem ao mercado financeiro, e particularmente o mercado de capitais, potencializar e apropriar-se de parte da riqueza produzida no processo de produção do espaço urbano. Este é o tema da próxima seção.

\section{OSFI e seus instrumentos}

O Sistema Financeiro Imobiliário (SFI) foi instituído durante o governo FHC, pela lei n. 9.514/1997, com a finalidade de "promover o financiamento imobiliário em geral" (art. 1ํ). A criação do SFI faz parte de um processo mais amplo de reestruturação da propriedade imobiliária e do financiamento imobiliário no Brasil, iniciado nos anos 1990. Vale lembrar que os Fundos de Investimento Imobiliário (FIls) foram criados em 1993 e traziam consigo uma nova forma de funding imobiliário e de propriedade dos imóveis ${ }^{2}$ (Fix, 2011).

A estruturação de um outro sistema de financiamento imobiliário deu-se no sentido de construir as conexões entre a esfera financeira e o ambiente construído urbano que não eram possíveis dentro do $\mathrm{SFH} .{ }^{3}$ Elaborou-se, assim, uma nova engenharia financeira, acompanhada de um novo arcabouço jurídico e regulatório, para financiar o mercado imobiliário via mercado de capitais e em contraposição aos "velhos instrumentos" do SFH, como o FGTS e o SBPE, que estavam comprometidos com as "amarras" das exigibilidades, tais como teto de valor financiado, limite de taxas e indexação atrelada à Taxa Referencial (TR) (Melazzo e Abreu, 2019; Royer, 2009).
$\mathrm{O}$ amadurecimento do SFI tem se manifestado através de duas tendências, conforme identificadas por Pereira (2015). A primeira refere-se ao reforço da segurança jurídica dos credores através da instituição de mecanismos que facilitam a execução das garantias reais nas operações de concessão de crédito, tais como a alienação fiduciária, o regime fiduciário e o patrimônio de afetação. ${ }^{4} \mathrm{~A}$ segunda tendência refere à criação de novos títulos financeiros de base imobiliária como os CRIs, as LCls (Letras de Crédito Imobiliário), as CCls (Cédulas de Crédito Imobiliário) e, mais recentemente, as Letras Imobiliárias Garantidas (LIGs).

Os principais títulos financeiros, em termos de volume de recursos, criados no âmbito do SFI são as LCls e os CRIs. Ao analisar a evolução dos estoques dos ativos financeiros criados pelo SFI entre o final dos anos $1990 \mathrm{e}$ 2015, Pereira (ibid.) conclui que as LCls foram o instrumento mais relevante na mudança do quadro geral do circuito financeiro imobiliário. Elas foram criadas pela lei n. 10.931 de 2004, conformando-se como um mecanismo de captação exclusivamente bancário. Na prática, os bancos emitem esses títulos financeiros ao mercado e utilizam o recurso captado para financiar uma carteira de crédito imobiliário preestabelecida, que não necessite estar sob as exigibilidades do $\mathrm{SFH}$, dado que o funding não provém da poupança. Ao contrário dos CRIs, o lastro das LCls não são as operações de financiamento imobiliário a que se destinam, mas a capacidade de solvência da instituição financeira emissora. Pereira (ibid.) alega que esse instrumento tem sido utilizado de forma semelhante à poupança pelos bancos, uma vez que sua captação ocorre de maneira pulverizada. Além disso, atrai os investidores de varejo por oferecer uma rentabilidade superior 
à poupança e a outros ativos de renda fixa com risco similar. A questão central pontuada pelo autor é de que esse instrumento absorve recursos antes destinados às exigibilidades do SFH, devido a sua competição com a poupança, ocasionando um deslocamento progressivo do funding bancário em direção às operações com maior rentabilidade, uma vez que as LCls estão associadas aos financiamentos de imóveis residenciais de alto padrão, enquanto os recursos da poupança estão enquadrados aos critérios do SFH. Essa ponderação indica uma contradição na evolução do SFI: enquanto no plano do discurso a intenção do novo sistema seria de deslocar o centro gravitacional do financiamento imobiliário do mercado bancário para o mercado de capitais, o resultado foi o inverso.

$\mathrm{O}$ estoque de $\mathrm{LCl}$, contudo, vem apresentando tendência de queda desde 2018, momento em que foi promulgada a resolução CMN n. 4.676, que desvinculou o crédito imobiliário concedido com recursos da poupança (pelas entidades do SBPE) das exigibilidades de direcionamento para o SFH. Com os recursos da poupança agora disponíveis para financiamento de imóveis residenciais a qualquer valor e taxa, as LCls perderam seu caráter de um instrumento de financiamento adicional para os bancos e tornaram-se desvantajosas devido ao custo de captação ser maior que a poupança.

O Certificado de Recebíveis Imobiliários (CRI) é definido pela legislação como um "título de crédito nominativo, de livre negociação, lastreado em créditos imobiliários e constitui promessa de pagamento em dinheiro" (lei n. 9.514/1997, art. 6ํ), sendo de emissão exclusiva das companhias securitizadoras. ${ }^{5}$ Ainda segundo Pereira (ibid.), os CRIs foram formatados como um produto financeiro destinado aos fundos de investimento e investidores qualificados. 0 público em geral poderia se aproveitar desse instrumento indiretamente, via os Fundos de Investimento Imobiliário que investissem especificamente em dívidas imobiliárias, os "fundos de papel". $\mathrm{Na}$ lógica proposta pela CVM, esse investimento nos CRIs, por meio de FII, estaria mais adequado ao perfil do investidor pessoa física, uma vez que este estaria terceirizando a análise de risco e a composição de um portfólio para um gestor profissional do mercado.

Apesar de criado em 1997, o CRI apresentou crescimento significativo apenas a partir de 2008 e, de maneira mais acentuada, a partir de 2011, quando o FGTS iniciou um ciclo de investimento no ativo, revelando a intenção do fundo em promover conexões entre os recursos do SFH e os instrumentos do SFI e sua capacidade de alavancar as operações de securitização no País (Royer, 2016). O FGTS, porém, não realizou mais aportes em CRI desde 2016, segundo os demonstrativos financeiros do fundo. $O$ estoque de CRI, de acordo com dados fornecidos pela Central de Custódia e Liquidação Financeira de Títulos Privados (Cetip), continuou a crescer desde então, apesar de ser em ritmo menor, indicando que o mercado primário está absorvendo as novas emissões sem a necessidade dos aportes do FGTS. Uma vez que a participação do FGTS na compra de CRI movimentava significativamente esse mercado no período 2011-2016, o que evidenciou o papel do fundo público na sustentação dessa vertente do processo de financeirização, é possível que se esteja assistindo ao início de um novo estágio da securitização no País, com predominância privada nas aquisições desses títulos. Recentemente, assistiu-se ao crescimento dos Flls enquanto detentores de CRI através 
da multiplicação dos "fundos de papel" e de novas emissões dos antigos fundos (Uqbar, 2019), alçando os Flls à categoria de principal financiador da securitização no País.

Tanto os Flls quanto os CRIs apresentaram, no momento de sua criação, a justificativa de que esses instrumentos poderiam dinamizar as fontes de financiamento imobiliário e habitacional no País, contribuindo, em última instância, para combater o déficit habitacional (Sanfelici e Halbert, 2018; Royer, 2009). Sabe-se, por meio de Sanfelici e Halbert (2018), que os Fundos de Investimento Imobiliário não obtiveram sucesso nesse sentido. A maior parte do patrimônio dos Flls está alocada em torres corporativas e shoppings centers, e poucos foram os Flls que se dedicaram ao desenvolvimento de projetos imobiliários habitacionais. Para os CRIs, a Uqbar (2019) ressalta que ainda não se assistiu ao verdadeiro potencial da securitização para o financiamento habitacional, mesmo que essas operações tenham se tornado "mais genuinamente de mercado," após o encerramento do ciclo de investimentos do FGTS em 2016.

Apesar de pouco ter avançado sobre o mercado habitacional, a securitização tem se expandido para outras esferas do ambiente construído urbano, envolvendo uma série de agentes nesse percurso. Este estudo inaugura, no Brasil, uma análise sobre os agentes cedentes de crédito imobiliário, buscando compreender o fenômeno da securitização em sua raiz, no exato momento em que as empresas lançam mão desse dispositivo para transformar rendas imobiliárias em títulos financeiros. Interessa-nos, particularmente, os porquês da securitização (momento da emissão) e como ela se torna possível (momento da compra dos títulos). Apenas em Abreu (2019) está presente uma atenção ao momento da emissão dos créditos, entretanto, circunscrito às emissões da Caixa Econômica Federal (CEF) entre 2011 e 2016 e sua relação com a compra dos títulos por parte do FGTS, tema anteriormente trabalhado por Royer (2016). Contudo, falta uma perspectiva que englobe os diversos atores que, em conjunto, determinam os rumos da securitização imobiliária no País. Isso é especialmente importante quando, a partir de 2016, tanto a Caixa quanto o FGTS diminuem drasticamente sua participação no mercado de securitização e ele continua a crescer. Parte-se do suposto de que é possível agrupar esses atores, mapear interesses similares de modo a extrair um referencial teórico mínimo - os agrupamentos - capaz de auxiliar na compreensão tanto da atual dinâmica do crédito habitacional quanto da dinâmica do capital financeiro. Não se pretende esgotar nem mesmo definir qual o melhor enfoque analítico para se explorar o que parece ser um novo estágio da securitização no País, mas sugerir uma forma de olhar para esse processo que valorize o caráter multifacetado da securitização.

Como se verá adiante, não só novos agentes emergem em importância nesse processo, sob a ótica do volume de recursos movimentados, como também o objeto imobiliário securitizado tem tomado rumos distintos do que era anteriormente observado, o que, por sua vez, reforça um caráter divergente do processo de financeirização imobiliário no Brasil com relação às experiências internacionais. 


\section{Evolução das operações de securitização imobiliária no Brasil}

A base de dados sobre as operações de securitização foi obtida através da técnica de mineração de dados conhecida como Webscraping ${ }^{6}$ no site da Anbima. A instituição vem coletando dados dos CRIs gerados pelas companhias securitizadoras desde 2014 e os fornece para consulta pública em seu site. ${ }^{7}$ Apesar de as informações se constituírem como uma amostra, ao serem comparadas com o volume financeiro de CRI registrado na CVM, percebe-se uma cobertura de $81 \%$ do universo de CRIs emitidos entre 2005 e novembro de 2021 (Gráfico 1).
A fim de se realizar uma análise dos agentes cedentes de crédito, eles foram agrupados em cinco categorias: 1) Bancos; 2) Companhias Hipotecárias; 3) Fundos de Investimento Imobiliários (FII); 4) Empresas Imobiliárias; e 5) Outros. 0 agrupamento balizou-se pela existência de palavras-chave na razão social dos cedentes. ${ }^{8}$

O Gráfico 2 mostra a participação dos grupos de cedentes de crédito imobiliário entre 2005 e novembro/2020. Apesar da extensão da amostra, em uma parcela considerável dos dados, não estão identificados os cedentes nas operações de securitização. São 475 séries, em que esses agentes não estão caracterizados e, em volume financeiro, eles somam $27 \%$ do total no período.

Gráfico 1 - Volume* securitizado da amostra e do universo (2005-2019)

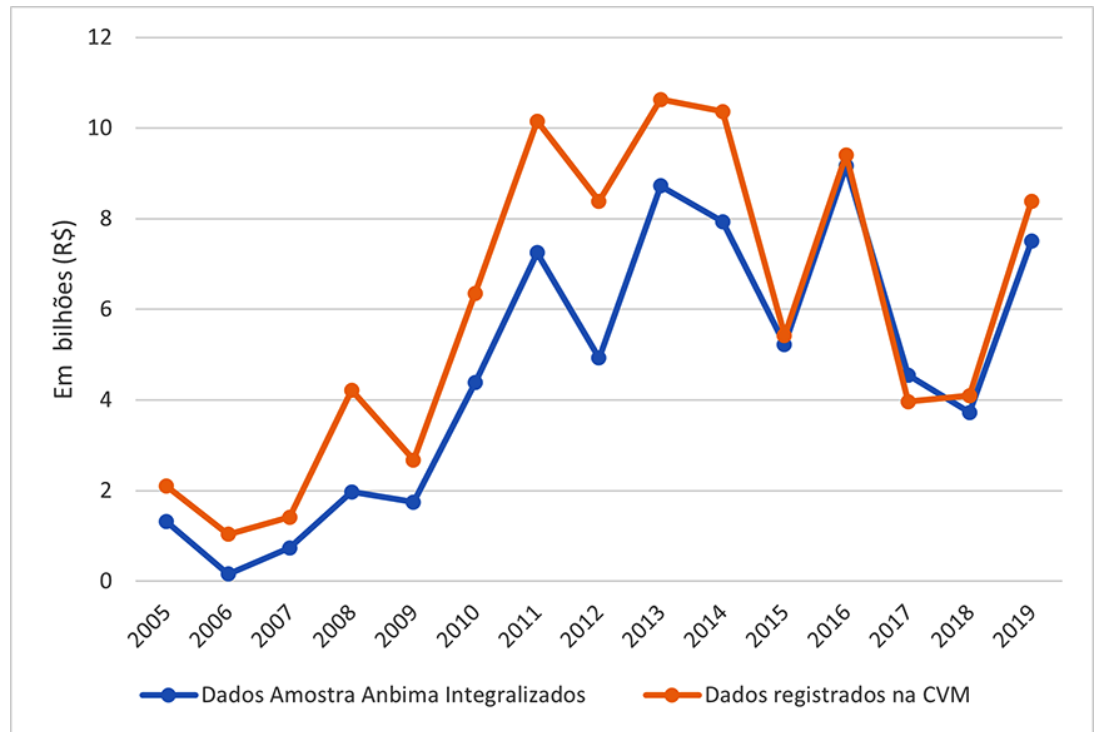

Fonte: Elaboração própria, a partir dos dados da Anbima (2014) e CVM.

*valores reais deflacionados pelo IPCA (ano-base de 2005). 
Percebe-se a relevância das instituições bancárias na securitização no País, mas não só. A cessão de créditos comporta uma miríade de agentes cuja principal aglutinação, após os bancos, seria o grupo das empresas imobiliárias, abarcando desde construtoras, incorporadoras e urbanizadoras até administradoras de toda sorte de imóveis - de lajes corporativas e condomínios logísticos a shoppings centers. Tal fato levanta um questionamento novo para a literatura sobre financeirização do imobiliário a respeito da relevância e do papel que esses agentes desempenham no processo de securitização. A seção "As empresas imobiliárias" propõe a hipótese de que as Empresas Imobiliárias tenham se utilizado da cessão de recebíveis imobiliários como um mecanismo financeiro para acelerar a rotatividade do capital.
O Gráfico 3 mostra a evolução do volume securitizado segundo a principal classificação desses ativos em nível mais agregado, conforme proposto pela Anbima (2014). Os CRIs concentrados são aqueles em que $20 \%$ ou mais do lastro da operação está vinculado a apenas um devedor e pulverizado quando o lastro das operações está fragmentado entre múltiplos devedores. Em geral, os CRIs concentrados estão associados aos créditos direcionados para o segmento corporativo ( $94 \%$ das operações), enquanto os pulverizados estão relacionados ao segmento residencial ( $87 \%$ das operações).

O Gráfico 3 revela uma dimensão da securitização no Brasil que a difere significativamente da experiência internacional, em particular da americana, vista como um modelo ou um estágio mais avançado a ser

Gráfico 2 - Volume securitizado por categoria cedente (2005-nov/2020)

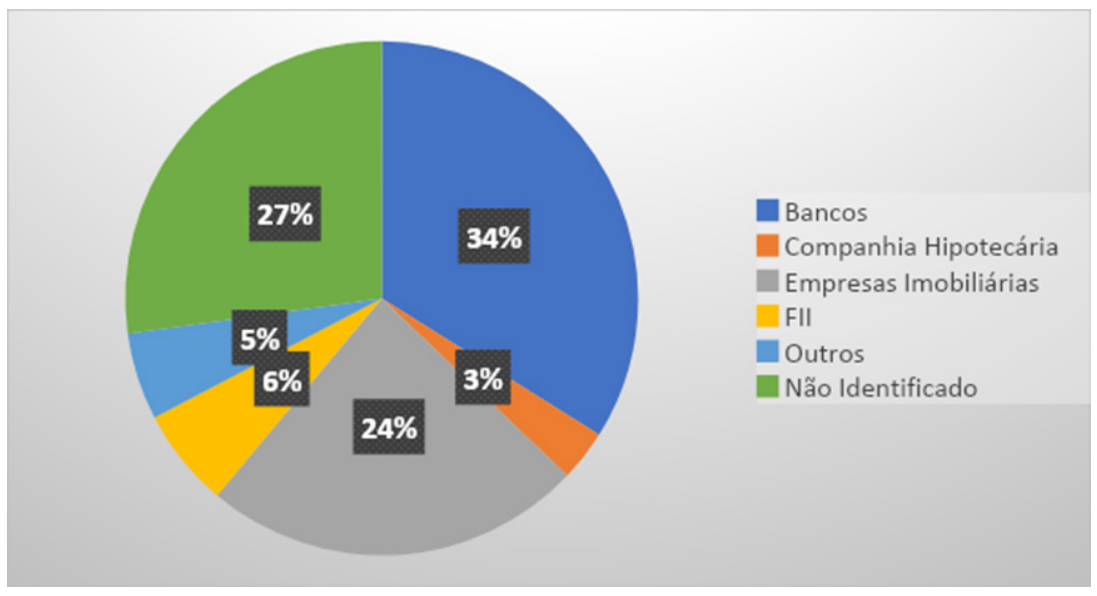

Fonte: elaboração própria a partir dos dados da Anbima (2014). 
Gráfico 3 - Evolução* dos CRIs por concentração (2005-2019)

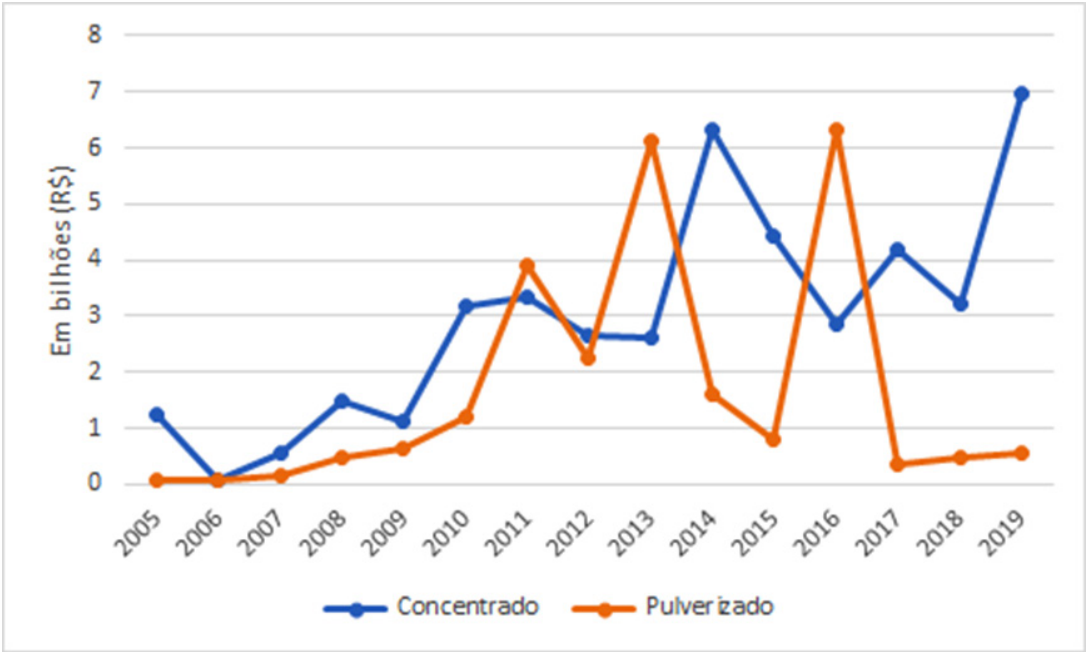

Fonte: elaboração própria, a partir dos dados coletados no site da Anbima.

* Valores reais deflacionados pelo IPCA (ano-base de 2005).

alcançado: a predominância das operações corporativas ou comerciais sobre as residenciais. Para a economia americana, por sua vez, segundo os dados da Securities Industry and Financial Markets Association (Sifma) e considerando o mesmo período da amostra da Anbima, a securitização residencial representou $81 \%$ do volume total das hipotecas securitizadas (Mortgage Backed Securities, MBS)..$^{9}$ Os dois casos, entretanto, apresentam um aspecto fundamental em comum: o papel do Estado no impulsionamento dessas operações. Nos EUA, o mercado secundário foi patrocinado pelo governo americano através das Government Sponsored Enterprises (GSE), que concediam garantias para as operações de securitização. As GSE foram responsáveis por colocar a maior parte desses títulos no mercado, gozando alguns papéis de risco zero (o mesmo que os títulos públicos), dado que o governo americano cobria o principal e os juros em caso de calote (Coles e Hardt, 2000). No Brasil, o Estado atuou pela via da demanda, acionando o FGTS para aquisição de CRIs residenciais no período 2011-2016. Embutido na ação do Estado, havia o intuito de gerar uma liquidez inicial para o mercado secundário desses títulos (Royer, 2016). Posteriormente, Abreu (2019) chamou a atenção para o fato de que o Estado brasileiro teve papel importante também na oferta dos títulos através da cessão de créditos habitacionais pela Caixa no mesmo período.

A predominância das operações com lastro corporativo sobre as operações residenciais, majoritariamente ofertadas e adquiridas por entes do Estado, ressalta que há limites significativos no processo de securitização do crédito habitacional pela via do mercado, 
reforçando uma hipótese importante: a de que, sem o patrocínio do Estado, não é possível haver um processo de financeirização da moradia. Royer (2016) e Abreu (2019) haviam demonstrado a relevância do Estado para a securitização residencial no País; à luz dos novos dados, é possível perceber que o Estado não é apenas importante, mas central nesse processo.

Ainda no Gráfico 3, o olhar para a securitização, considerando a composição entre o lastro corporativo e o lastro residencial, contrasta com algumas percepções da literatura recente acerca da presença cada vez maior de imóveis residenciais nos pacotes de securitização (Melazzo e Abreu, 2019). o que se vê, na verdade, é um cenário de securitização residencial descontínua e uma securitização com lastro corporativo mais consistente e crescente. A próxima seção analisará esse cenário sob a perspectiva dos grupos de agentes envolvidos na securitização imobiliária.

\section{Análise dos agentes da securitização imobiliária no Brasil}

\section{O papel do FGTS}

O Gráfico 4 retrata a evolução das operações de securitização exclusivamente residenciais. Adicionam-se, ainda, duas informações importantes: o volume securitizado pelas instituições financeiras (oferta) e o volume aplicado pelo FGTS na compra de CRI no período (demanda).

Ele reforça o que vinha sendo pontuado pela literatura nacional a respeito do papel do FGTS no impulsionamento do mercado de títulos financeiros atrelados a imóveis, principalmente os CRIs (Royer, 2016; Abreu, 2019). Contudo, o que o Gráfico 4 traz de novidade para a discussão sobre financeirização do imobiliário no Brasil não é apenas a relação do

Gráfico 4 - O papel das instituições bancárias e do FGTS na securitização residencial (2005-2020)

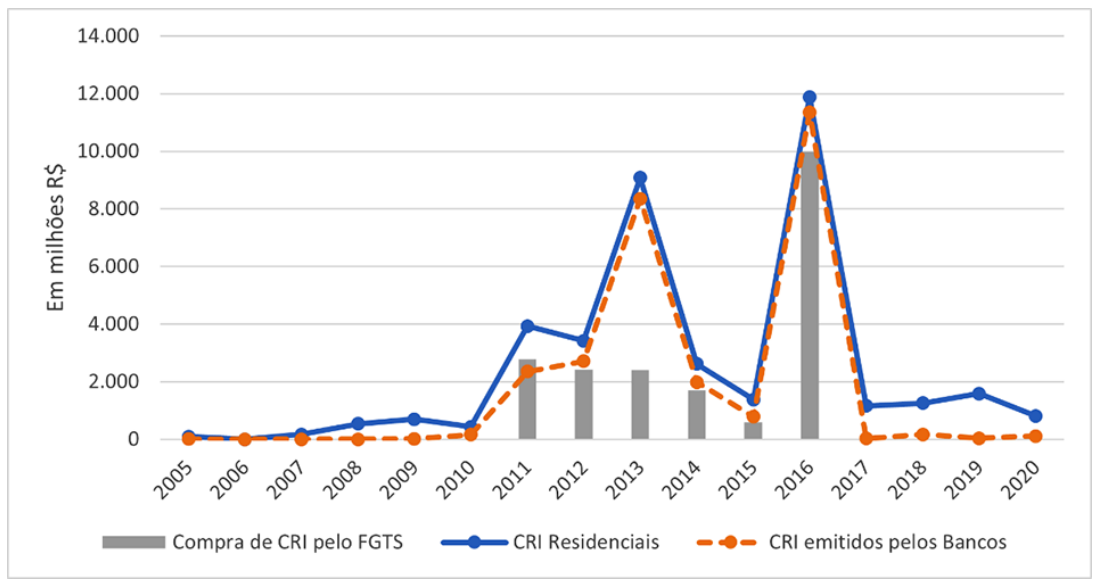

Fonte: elaboração própria, a partir dos dados coletados no site da Anbima e do FGTS. 
FGTS com a securitização residencial, mas a dependência desta com relação aos recursos do fundo. Em outras palavras, a oferta de CRI dos bancos foi quase inteiramente absorvida pelo FGTS. Para além disso, o gráfico aponta, ainda, para um outro aspecto relevante: a falta de um movimento espontâneo por parte dos bancos para a securitização de suas carteiras de financiamento imobiliário. Esses dois pontos marcam profundamente a securitização residencial no País e merecem análise à parte.

Se a securitização residencial evoluiu apenas na medida em que o FGTS se dispôs a investir na aquisição de CRI, vale a pena explicitar as motivações do fundo por trás desse processo. Ao menos três fatores estão relacionados ao ciclo de aquisições de CRI por parte do FGTS e que ora se reforçam, ora entram em conflito, conforme se depreende das exposições dos conselheiros do CCFGTS presentes nas atas das reuniões do colegiado no período 2010-2016.

Em primeiro lugar, conforme ressaltado por Royer (2016), havia a intenção do fundo de impulsionar a liquidez desses títulos financeiros no mercado secundário sob a justificativa de que se estimulariam novos projetos habitacionais. A aquisição de CRI sempre esteve permeada pelo discurso de combate ao déficit habitacional e apresentava uma "visão de futuro" ${ }^{10}$ ao se utilizar dos instrumentos criados no âmbito do SFI enquanto ferramenta de promoção da política habitacional. Persistia e reforçava-se, assim, aquela matriz ideológica do SFI que se contrapunha ao SFH, este último considerado ineficiente e insuficiente.

Em segundo lugar, por ser um veículo de investimento cujo objetivo é preservar o valor dos celetistas ao longo do tempo, o FGTS procura equilibrar a aplicação em investimentos rentáveis ao mesmo tempo que cumpre seu papel social de financiar a habitação popular, o saneamento e a infraestrutura. Nesse contexto, os CRIs apresentavam-se como instrumentos que geravam rendas continuamente. ${ }^{11}$

Por fim, o investimento em CRI, em alguns momentos, esteve associado à utilização do FGTS enquanto braço da política fiscal do governo federal. Em 2016, o ano em que o FGTS aplicou um volume inédito nessas operações, a motivação do fundo era amortecer os impactos da recessão econômica de 2015 e 2016. Através da análise das atas do CCFGTS, é possível perceber como o FGTS encomendou os CRs junto às principais instituições financeiras do País. Ao comprar esses pacotes de financiamentos e retirar crédito imobiliário do balanço dos bancos, o FGTS abria espaço para que essas instituições pudessem conceder novos empréstimos, uma vez que deveriam continuar a atender os critérios de exigibilidade do SFH. Dessa maneira, viabilizou-se uma política fiscal anticíclica sem a utilização de recursos do Tesouro Nacional. As atas do CCFGTS revelam que nem sempre há consenso entre os conselheiros quanto à execução orçamentária do fundo. 0 poderio de seus recursos e a capacidade de influenciar a dinâmica econômica o tornam uma arena de interesses dos segmentos econômicos representados no órgão colegiado.

Desse modo, conclui-se que o processo de financeirização do imobiliário no Brasil, sob a ótica da securitização dos financiamentos habitacionais, permaneceu circunscrito à política de alocação de investimentos por parte do FGTS (em um movimento conjunto com os bancos). Política esta permeada por outras motivações para além do puro retorno sobre as aplicações. 0 projeto de se construir uma 
estrutura alternativa de funding imobiliário no País não logrou. Sem a participação do fundo na aquisição dos CRIs residenciais, após 2016, essa fonte de recursos se tornou inexpressiva ante as demais estruturas de financiamento habitacional. Contudo, cumpriram um papel fundamental na dinâmica do capital financeiro, como se verá adiante: o aprofundamento da conexão entre o mercado de capitais e o mercado imobiliário (fora do segmento residencial).

\section{O lugar dos bancos}

A securitização residencial no Brasil foi ditada, em grande parte, por um movimento conjunto entre os bancos, cedendo suas carteiras de créditos, e o FGTS, comprando os títulos financeiros gerados. No Brasil, as instituições financeiras não ocuparam o papel de agente motor no processo de securitização. Esta seção busca explorar alguns motivos.

Uma das razões é o fato de que a maior parte dos CRIs emitidos no período, não só pelos bancos, mas também pelos demais agentes, possui algum tipo de coobrigação por parte do cedente. Dessa maneira, mesmo após a formatação de um CRI e sua venda, a instituição cedente permanece como responsável pelos pagamentos dos mutuários, não sendo possível transferir todo o risco da operação para os compradores dos títulos. Cerca de $62 \%$ de todo o financiamento imobiliário securitizado pelos bancos no período apresentaram alguma forma de coobrigação segundo os dados da amostra da Anbima. Segundo Crotty (2008), foi exatamente a possibilidade de terceirizar o risco das operações de crédito imobiliário para investidores dos títulos de securitização americana, agregado ao baixo custo das proteções contra calotes, que resultou no aumento das margens dos bancos nos EUA sem aumento correspondente no risco dessas operações durante o período pré-crise de 2007-2008. Dessa forma, os bancos geravam risco, mas não o absorviam (Dymski, 2009).

Outro fator que interferiu na securitização por parte dos bancos foi o atendimento das exigibilidades do SFH. Até 2019, antes de entrar em vigor a resolução CMN n. 4.676, 52\% do saldo da caderneta de poupança deveria ser destinado às operações no âmbito do SFH e, portanto, atrelado à TR, um indexador preterido pelos investidores de mercado sob alegação de que a taxa é determinada de maneira "artificial" pelo Banco Central (Uqbar, 2020). Esse fator fez com que a demanda em escala e solvável para os CRIs formatados pelos bancos fosse proveniente apenas do FGTS, que obrigatoriamente deveria investir em operações sob as condições do $\mathrm{SFH}$.

Esse cenário, entretanto, possui uma perspectiva de mudança não só pelo horizonte aberto pela resolução CMN n. 4.676, que destravou a concessão de financiamento imobiliários dos critérios do SFH, como também pelo novo direcionamento da Caixa, responsável por $26 \%$ de todo o financiamento imobiliário em 2019. ${ }^{12}$ Desde que assumiu o posto de presidente da instituição, em janeiro de 2019, sob o governo Bolsonaro, Pedro Guimarães declarou, como um dos objetivos do banco, ampliar a securitização no País, alegando velhos problemas de captação de recursos: "É fundamental discutir mais a parte imobiliária. Hoje, temos problemas de funding. Venderemos de $\mathrm{R} \$ 50$ bilhões a $\mathrm{R} \$ 100$ bilhões no mercado financeiro, cinco a dez vezes mais do que foi feito em toda a história". ${ }^{13}$ Em agosto de 2020, o presidente ratificou esse posicionamento e 
divulgou que o programa de securitização do banco, agora com créditos atrelados ao IPCA, somava $\mathrm{R} \$ 10$ bilhões. ${ }^{14}$ Apesar de a securitização residencial não ter tomado corpo até então, forma-se um cenário mais propício a essas operações através tanto dos recentes ajustes no ambiente regulatório quanto do novo posicionamento político-econômico da principal instituição de crédito imobiliário do País. Assim, um novo impulso à securitização poderá ser observado nos próximos anos por meio de um efetivo patrocínio do Estado nessa vertente da financeirização do imobiliário.

Se os bancos nacionais não se utilizaram da securitização como forma de expandir a rentabilidade sobre os financiamentos habitacionais, fizeram-na por meio da intermediação de serviços financeiros. A atuação dessas instituições tem se manifestado, sobretudo, no papel de coordenador-líder das emissões. 0 coordenador-líder é responsável pelo registro da oferta, por elaborar os documentos requeridos pelas agências reguladoras e por levar os títulos ao público, cobrando uma taxa da empresa ou do grupo de empresas cedentes do crédito. Durante todo o período disponível pela amostra de registro das emissões da Anbima, apenas cinco instituições foram responsáveis pela coordenação de $60 \%$ do volume emitido, sendo as três primeiras integrantes das maiores instituições bancárias do País (Quadro 1).

A atuação enquanto intermediários financeiros possibilitou, aos bancos, rentabilizarem a securitização imobiliária sem se envolverem no risco de tais operações. Nesse ponto, está em congruência com a experiência internacional, na qual uma parcela significativa da receita dos bancos está baseada mais em cobranças de taxas sobre os serviços financeiros do que sobre juros na concessão de empréstimos imobiliários (Dymski, 2009; Schwartz, 2012).

Quadro 1 - Concentração do papel de Coordenador-Líder nas emissões dos CRIs

\begin{tabular}{|l|c|c|c|}
\hline \multicolumn{1}{|c|}{ Coordenador-Líder } & № de Operações & $\begin{array}{c}\text { Volume Emitido } \\
\text { (em milhões R\$̦) }\end{array}$ & $\begin{array}{c}\text { Participação individual no } \\
\text { Volume Emitido (\%) }\end{array}$ \\
\hline Itaú BBA & 195 & 19.860 & 16,5 \\
Caixa & 16 & 18.443 & 15,4 \\
Banco Bradesco & 115 & 16.139 & 13,4 \\
RB Capital DTVM & 153 & 10.468 & 8,7 \\
BR Partners & 68 & 6.530 & 5,4 \\
\hline
\end{tabular}

Fonte: elaboração própria, a partir dos dados coletados no site da Anbima. 


\section{As empresas imobiliárias}

Observa-se, adentrando no escopo da securitização atrelada aos imóveis corporativos, que tem apresentado crescimento sistemático ao longo dos anos, a predominância da categoria Empresas Imobiliárias enquanto cedentes de créditos. 0 Gráfico 5 mostra as tipologias imobiliárias que estão sendo securitizadas por essas empresas.

Os segmentos com maior expressividade na amostra, as lajes corporativas e os shopping centers, são exatamente aquelas tipologias arquitetônicas que pouco se alteram conforme mudam as localizações, o que possibilita, aos investidores, reconhecerem um produto desvendado com expectativas de risco e rentabilidade conhecidas (Santoro e Rolnik, 2017). A concentração desses segmentos nos CRIs é semelhante à observada por Sanfelici e Halbert (2018) entre os imóveis sob gestão dos Flls. Nesse sentido, talvez não por acaso a classe dos Flls que investem predominantemente em CRI, os "fundos de papel", tenha se desenvolvido, sobretudo, nessas mesmas tipologias imobiliárias.

Esses fatores auxiliam a explicação da existência de uma demanda para os CRIs relacionados ao segmento corporativo. Contudo ainda resta explorar o porquê de as empresas imobiliárias lançarem mão desse dispositivo. A hipótese aqui proposta para responder a esse questionamento é de que as empresas imobiliárias têm se utilizado da securitização como forma de se autofinanciarem sem necessidade de alteração em sua estrutura de capital (ações e dívidas). Para o desenvolvimento do raciocínio será necessário recorrer a alguns conceitos contábeis e financeiros.

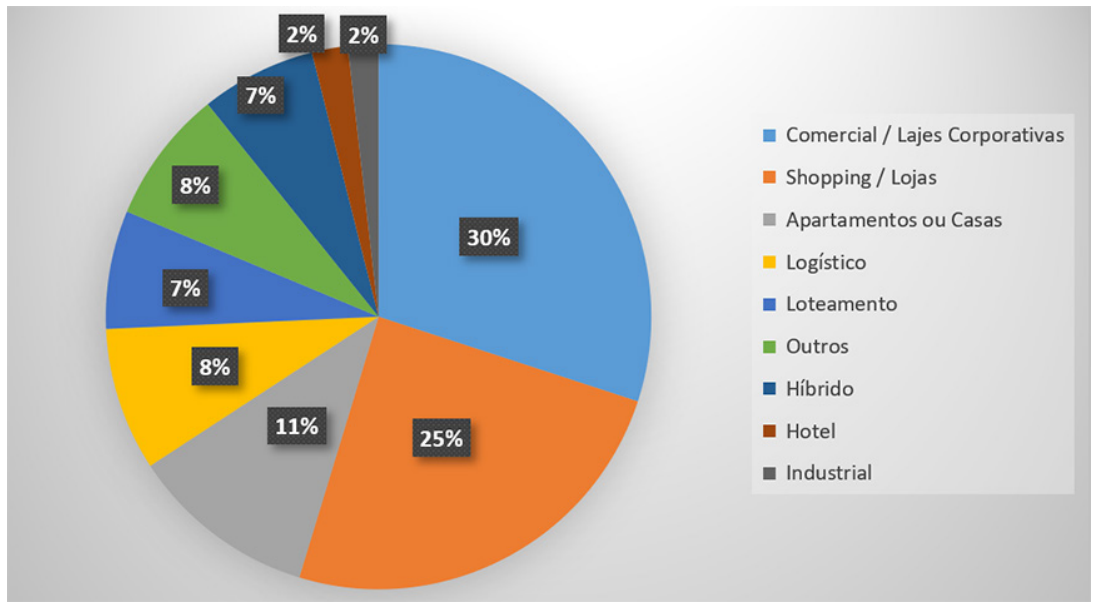

Fonte: elaboração própria, a partir dos dados coletados no site da Anbima. 
O balanço patrimonial é uma demonstração contábil que condensa as informações sobre as aplicações (ativo) e as fontes de recursos de uma empresa (estrutura de capital ou passivo). Uma empresa capta recursos de duas maneiras: 1) emissão de ações - que podem ser primárias no caso de IPO (Initial Public Offering) ou secundárias, quando a empresa já é negociada no mercado de ações; 2) aumento do endividamento, o que tende a ocorrer por meio da emissão de papéis no mercado financeiro - tais como as debêntures ou as notas promissórias. A estrutura de capital de uma empresa nada mais é do que a combinação entre essas duas fontes. Os recursos adquiridos são investidos nas atividades que a empresa se propõe a realizar (e gerar lucro). 0 ativo é o somatório de todos esses investimentos. $\mathrm{O}$ objetivo do gestor é maximizar a rentabilidade do ativo ao mesmo tempo que minimiza o custo da estrutura de capital, gerando, assim, o máximo de lucro possível.

A opção de securitização de contratos imobiliários leva a uma alteração nas rubricas do ativo da empresa: transformam-se recebimentos a prazo (aluguéis, contratos de financiamento) em caixa disponível no presente. A liquidez gerada pela securitização possibilita, às empresas, ensejarem novos ciclos de acumulação, comprando terrenos, financiando novos projetos imobiliários e adquirindo totalmente ou parcialmente imóveis. Ao acelerar o ciclo de rotação do capital, abre-se espaço para aumento das margens de lucro, elevando a rentabilidade do ativo ao longo do tempo. Assim, as empresas conseguem levantar caixa para a realização de novos investimentos por meio de alterações na estrutura do ativo, mantendo intocada a estrutura de capital sua fonte de financiamento tradicional. Daí o termo "autofinanciamento". Duas vantagens emergem desse processo do ponto de vista da gestão da estrutura de capital: 1) não sendo necessário emitir novas ações, não haverá risco de diluição do patrimônio dos atuais acionistas, o que acarretaria queda da rentabilidade no curto prazo; 2) não sendo necessário o aumento do endividamento, a empresa mantém indicadores de saúde financeira sob controle; caso contrário, a deterioração desses indicadores poderia se refletir negativamente na precificação da empresa, prejudicando os acionistas. Além disso, tanto a emissão de ações quanto o aumento do endividamento exigem uma capacidade de convencimento da empresa, junto ao mercado de capitais, de que a captação de recursos vale a pena.

Essa possibilidade teórica de utilização da securitização pelas empresas imobiliárias é sustentada em face da relevância dos recursos securitizados em relação aos recursos captados via alterações na estrutura de capital, tais como as debêntures e as ações (Gráfico 6):

Essa lógica de utilização da securitização, contudo, é uma possibilidade, contendo limites. 0 principal deles é a taxa de desconto a ser utilizada para a transformação do fluxo de recebimentos em um valor presente. Esse fator se agrava quando o País possui um histórico de altas de juros, o que exige das empresas que se utilizam desses instrumentos possuírem altas margens de lucro em seus projetos imobiliários. Isso, por sua vez, restringe a tipologia dos objetos imobiliários passíveis de securitização. Como visto anteriormente, a maior parte dos imóveis está associada ao segmento corporativo e não residencial. Após checagem da amostra, constatou-se que, quando residencial, a securitização imobiliária está circunscrita a condomínios de luxo e a resorts 
Gráfico 6 - Participação das principais fontes de captação de recurso das empresas imobiliárias e o volume de créditos securitizados (2014-2019)

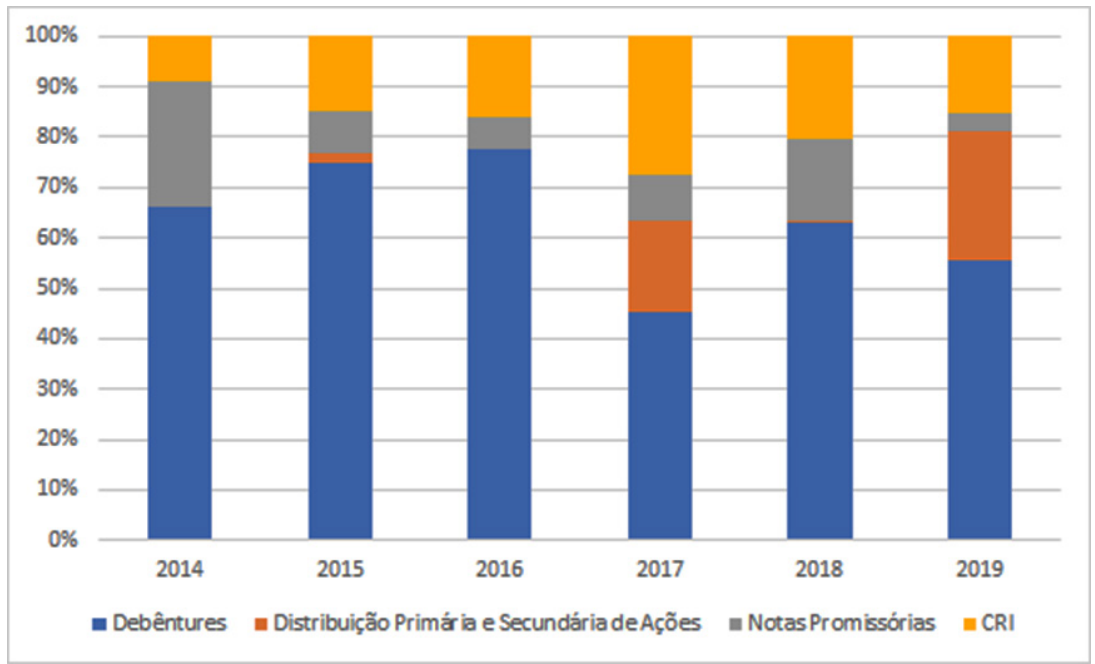

Fonte: elaboração própria, a partir dos dados coletados no site da Anbima e de outras fontes de informações da Anbima.

nacionais concentrados em poucas cidades. Por fim, a presença de coobrigação do cedente do crédito imobiliário nos contratos de securitização não permite a terceirização completa do risco de não pagamento na ponta das operações. Desse modo, em caso de inadimplência dos contratos que lastreiam o CRI, a empresa cedente tem de arcar com possíveis prejuízos aos detentores dos títulos.

Os CRIs gerados pelas empresas imobiliárias, para além de seu papel na esfera da produção, a que se chama a atenção neste estudo, ou seja, no aumento da velocidade de rotação do capital imobiliário, reforçam duas vertentes do processo de financeirização do imobiliário destacados pela literatura. Em primeiro lugar, abastecem o mercado de capitais com títulos lastreados em imóveis e que conferem fluxos de pagamentos contínuos, alimentando o aspecto rentista do mercado financeiro. Esse fenômeno tem reposicionado o questionamento da incompatibilidade entre acumulação de capital e rentismo (Paulani, 2016). Segundo, reforçam e são reforçados pelo asset manager capitalism (Brett, 2016), observado através da multiplicação de fundos e gestores profissionais que buscam absorver cada vez mais patrimônio sob gestão, ampliando a base sobre a qual são cobradas as taxas de administração. 


\section{Os Fundos de Investimento Imobiliário (FIls)}

Ao longo de sua história, os Flls foram um veículo de investimento mais associado à "geração de renda passiva", ou seja, à extração de renda da terra de forma semelhante ao capital portador de juros, do que ao asset manager capitalism que visa, por meio das especulações de curto prazo, "bater o mercado", obtendo ganhos acima da média. Esse quadro tem se alterado através do novo boom das emissões recentes de FII, com as principais categorias de gestão ativa, tendo ultrapassado a proporção de gestão passiva (Gráfico 7).

Essa inflexão na estratégia por parte dos gestores de FII acrescenta novos atores ao rol dos "profissionais da antecipação urbana" (Abramo, 2007), alimentando a especulação espacial. Essa tendência, todavia, está concentrada nos principais centros urbanos do País, especialmente São Paulo e Rio de Janeiro, e às tipologias comerciais de alto padrão, como torres e lajes corporativas (Sanfelici e Halbert, 2018; Santoro e Rolnik, 2017).

Chama-se a atenção para o crescimento dos Flls de Títulos e Valores Mobiliários (TVM), os "fundos de papel". Vê-se como a vertente especulativa que absorve o patrimônio imobiliário também se estende para a absorção de dívidas imobiliárias. É nesse movimento que se encontram as respostas para o novo momento da securitização no País, no qual o FGTS deixa de exercer o papel de principal financiador dessas operações, dando lugar aos dispositivos financeiros que intermedeiam recursos entre o mercado imobiliário e o mercado de capitais.

\section{Gráfico 7 - Evolução das principais categorias de FII no período recente (jul/2019-nov/2020)}

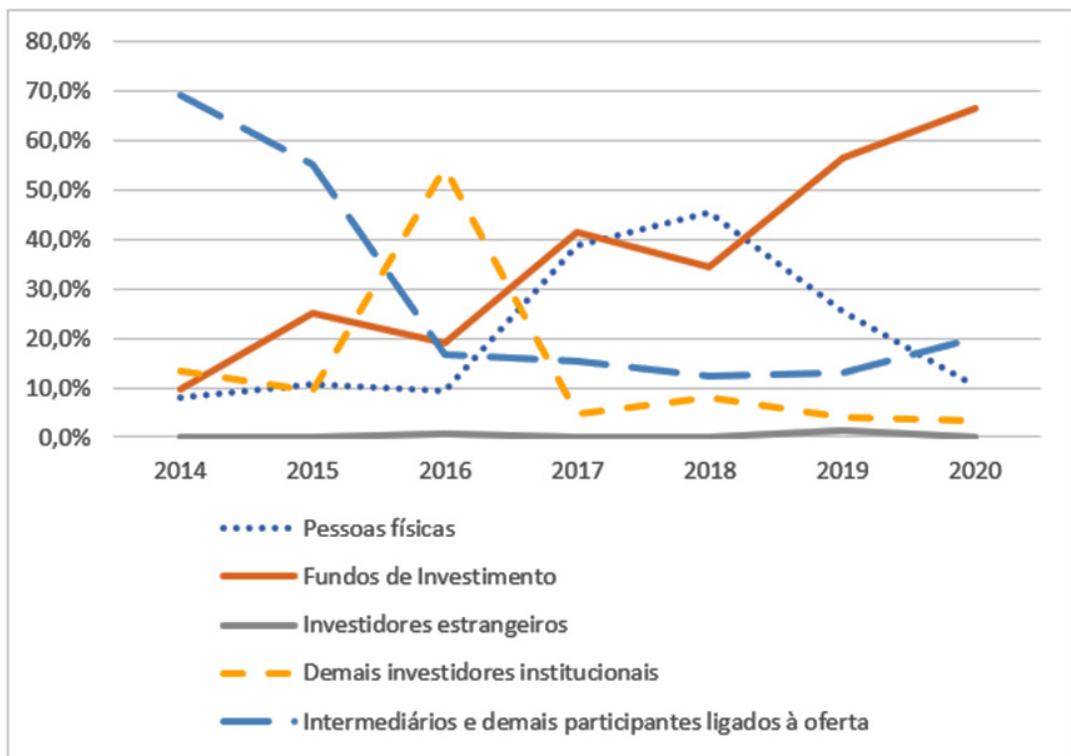

Fonte: elaboração própria, a partir dos dados da Anbima. 
Através das informações da Anbima sobre os subscritores das emissões de CRI de 2014-2020, os fundos de investimento, majoritariamente FII, saíram de uma participação de $10 \%$ nas aquisições de CRIs emitidos em 2014 para mais de 60\% em 2020 (Gráfico 8).

Percebe-se, ainda, como essa mudança na estrutura de funding da securitização está associada à uma mudança no objeto securitizado. Enquanto o FGTS possibilitou a expansão da securitização residencial, os recursos dos Flls têm sido a base para a securitização imobiliária do segmento corporativo. Tal fato põe em xeque a capacidade desses instrumentos financeiros de ampliar o financiamento habitacional no País, um dos principais elementos contidos no discurso de sua criação (Royer, 2009; Sanfelici e Halbert, 2018).
Ainda há um outro ponto importante de diferença entre esses agentes. Ao contrário do FGTS, que mantinha um comportamento do tipo hold to maturity (matinha o ativo até a data de vencimento) para com os CRIs, o que reduzia a liquidez desses ativos no mercado secundário (Anbima, 2014), os gestores de FII, ao proporem uma gestão ativa de suas carteiras, elevaram a frequência de negociação no mercado secundário com objetivo de se aproveitarem de oscilações de curto prazo, principalmente das taxas de juros. Segundo dados disponíveis na B3, enquanto o volume de negociações de CRI anualmente esteve em um intervalo de $\mathrm{R} \$ 10$ bilhões a $\mathrm{R} \$ 25$ bilhões no período 2011-2019, apenas em 2020 foram negociados cerca de R\$70 bilhões de CRI no mercado secundário.

Gráfico 8 - Distribuição das ofertas de CRI por detentor (2014-2020)

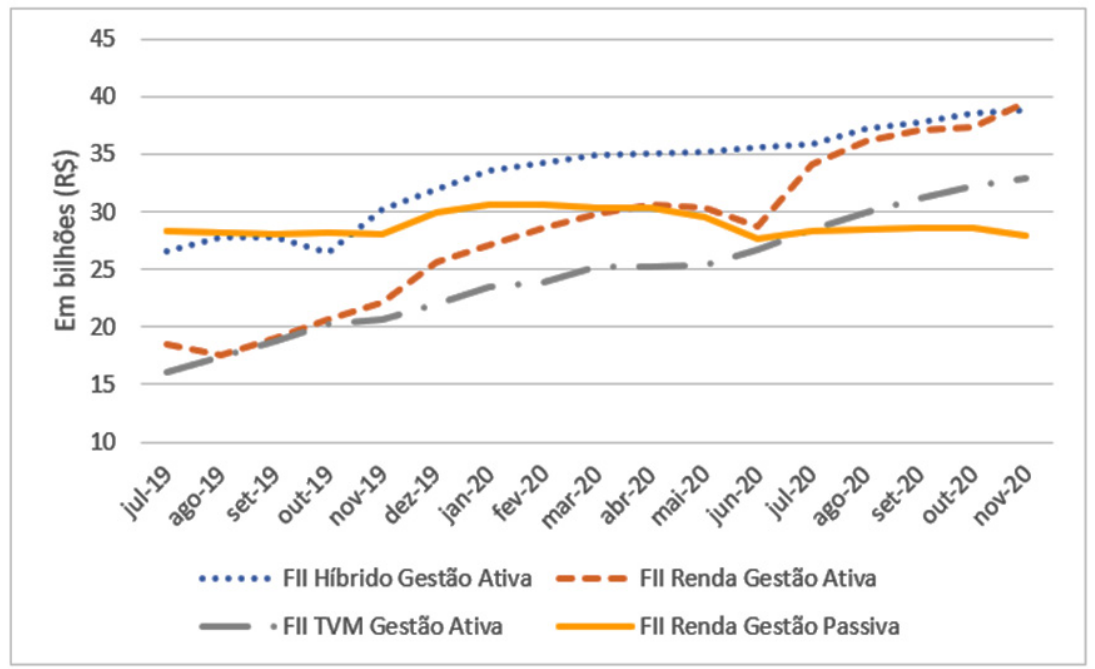

Fonte: elaboração própria, a partir dos dados da Anbima. 
Todo esse processo, que gera e nutre novos vetores para a especulação urbana, na medida em que potencializam esses canais de fluxos de mais-valor abertos pelos instrumentos financeiros, entretanto, pode estar relacionado ao ciclo das taxas de juros. Coincidentemente, o processo de queda das taxas de juros inicia-se no exato momento em que o FGTS encerrou o ciclo das aquisições de CRI. Com a Selic nominal atingindo suas mínimas históricas, a captação de recursos dos Flls através de emissões primárias e secundárias alcançou volumes recordes (Gráfico 9). Juros dos títulos públicos mais baixos tornam os imóveis e as cotas dos Flls mais atraentes aos especuladores financeiros. Assim, quando os juros caem, esses títulos e as cotas de Fll se valorizam, tudo o mais constante.
Apesar das baixas taxas de juros atualmente - em parte devido às políticas monetárias mais frouxas adotadas sob o governo Trump, e, posteriormente, devido à pandemia -, as principais projeções, tanto para o Brasil quanto para o exterior, apontam para uma elevação da taxa de juros no longo prazo. Isso levanta dúvidas sobre a continuidade do processo de financeirização vista pela ótica da expansão da securitização e do aumento patrimonial sob gestão dos Flls, tanto os "de tijolo" quanto "os de papel". Nesse ponto, o destino dessa vertente do processo de financeirização do imobiliário permanece atado às condições impostas pela política monetária: it takes two to tango.

Gráfico 9 - Evolução das emissões anuais de FII

e Taxa Selic Ponderada ao dia (2004-2020)

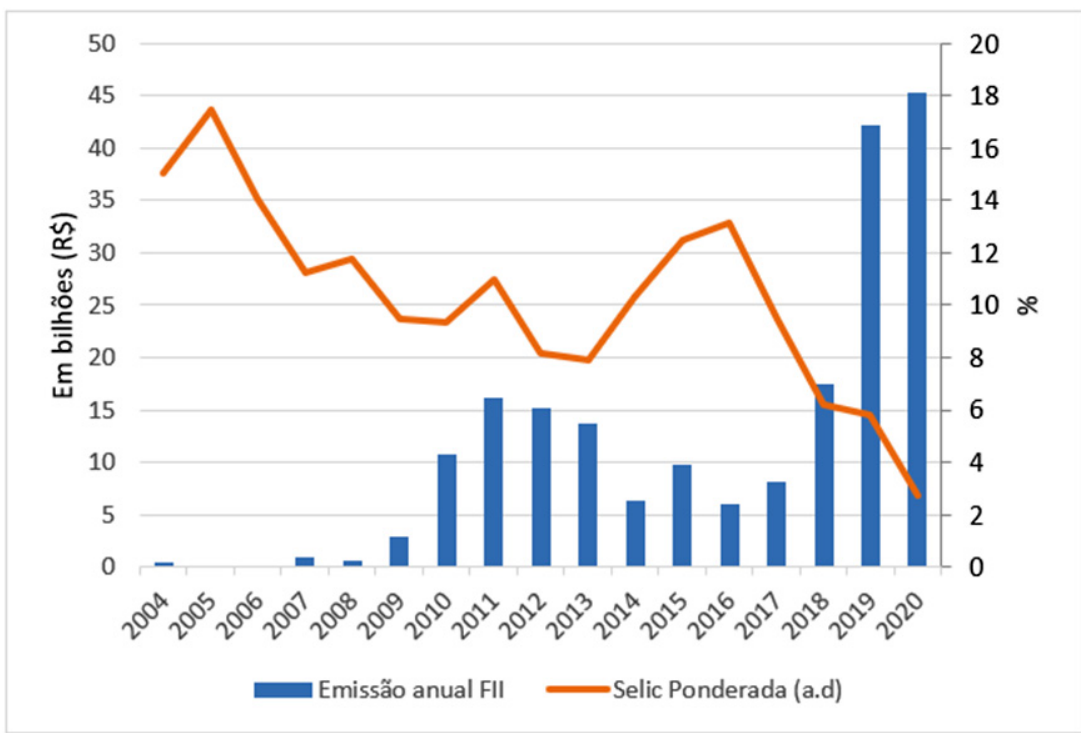

Fonte: elaboração própria, a partir dos dados da CVM e do Banco Central. 


\section{Conclusões}

Há algumas décadas, um conjunto de autores tem se debruçado e construído um arcabouço teórico que reposicionou o imobiliário como um elemento central na dinâmica do capitalismo contemporâneo, imerso em uma fase de financeirização. Na esteira das contribuições, o conceito e o tema da financeirização do imobiliário desenvolveram-se buscando abarcar as inúmeras formas, camadas e manifestações desse processo cuja pedra angular seria a securitização imobiliária. Em termos mais amplos, trata-se de uma nova relação do capital com o espaço, no qual a terra deixa cada vez mais de ser valor de uso ou meio de produção para se tornar ativo financeiro, governado pela lógica especulativa de maximização de rendas fundiárias, presentes e futuras (Haila, 1988; Harvey, 2006).

Este estudo procurou compreender a dinâmica da securitização enquanto uma vertente importante desse processo de financeirização do imobiliário no Brasil. Propôs-se, como metodologia, o agrupamento dos agentes envolvidos na cessão dos créditos imobiliários (o que se estendeu também aos compradores dos títulos), a fim de se mapear as distintas motivações que guiam o processo de securitização. Essa ferramenta analítica simples permitiu uma visão sobre securitização que tende à compreensão de seu movimento como um todo. Isso foi particularmente importante quando, no período de 2005-2020, assistiu-se ao predomínio de diferentes agentes tanto na cessão quanto na compra dos CRIs, o que, por sua vez, impactou o objeto imobiliário a ser securitizado.
Da escolha metodológica, surgiram dois novos agentes ainda pouco explorados pela literatura sobre financeirização do imobiliário, no que se refere ao seu entrelaçamento com as operações de securitização: as empresas imobiliárias e os Fundos de Investimento Imobiliário (FII), particularmente os Flls "de papel". Destrincharam-se as motivações por trás desses dois agentes, cada qual atuando em uma ponta do processo de securitização. Em uma ponta, as empresas imobiliárias gerando os CRIs (lastreados em construções) para acelerar os ciclos de acumulação do capital imobiliário. Na outra, os Flls financiando essas operações por meio da compra dos títulos, cumprindo, ao mesmo tempo, a finalidade de nutrir a face rentista do mercado de capitais com títulos financeiros de base imobiliária e de ampliar o patrimônio sob gestão sobre o qual são cobradas as taxas de administração que remuneram os gestores financeiros. Este estudo aponta que estas - empresas imobiliárias e Flls - são as novas forças motoras por trás da securitização desde 2016, a partir de quando o FGTS e a Caixa (mas também outros bancos) deixaram de atuar com relevância nesse mercado na ponta compradora e fornecedora, respectivamente.

As alterações na composição dos agentes cedentes de crédito imobiliário (e financiadores) implicaram, por sua vez, uma mudança no objeto imobiliário securitizado. 0 predomínio das operações com lastro corporativo em relação ao lastro residencial relativiza a proposição da disseminação crescente da securitização residencial conforme sugerida por Melazzo e Abreu (2019). A descontinuidade da securitização residencial e sua dependência 
dos movimentos do FGTS e da Caixa, por sua vez, reforçam a tese da centralidade do Estado no processo de financeirização da moradia pela via da securitização que se depreende dos trabalhos de Fix (2011), Royer (2016) e Abreu (2019). Assim, o "impulso inicial”, dado pelo FGTS no mercado de CRI, não resultou em um movimento autônomo e contínuo do mercado privado na utilização das operações de securitização residenciais. Estas, quando ocorreram, apresentaram volume desprezível ante as demais fontes de recursos do funding habitacional no País e circunscritas a espaços urbanos pouco representativos para a questão habitacional, tais como condomínios de luxo e resorts nacionais.

Tais considerações marcam um traço distinto da securitização no País com relação às experiências internacionais, em que predominam o lastro residencial. Alguns fatores contribuem para elucidar essa distinção: 1) a utilização de um indexador tido como "artificial" pelo mercado nos contratos de financiamento habitacional - a TR; 2) a presença de coobrigação do cedente de créditos na formatação dos CRIs, limitando a terceirização do risco para os adquirentes; 3) uma possível motivação dos bancos em rentabilizar essas operações mais a partir da intermediação do que da efetiva securitização da sua carteira de recebíveis imobiliários.

Compreende-se que esses contornos locais do processo de financeirização do imobiliário no País, visto sob a ótica da securitização imobiliária, sofrem influência de outros fatores que estão além do escopo deste trabaIho. Em particular, destaca-se a questão dos juros sob o rentismo brasileiro, que, futuramente, poderá fornecer respostas acerca dos limites da financeirização na periferia, principalmente, considerando-se a forte competição entre a dívida pública e outras fontes de ganho financeiro. A investigações sobre interesses, dinâmicas e contradições entre os agentes do Estado e do mercado envolvidos no processo de financeirização do imobiliário, via operações de securitização, continua crucial para a compreensão crítica das tendências mais recentes de financiamento do acesso à moradia e da produção do espaço urbano no Brasil

\section{[I] https://orcid.org/0000-0002-7450-5031}

Universidade Federal de Minas Gerais, Faculdade de Ciências Econômicas, Centro de Desenvolvimento e Planejamento Regional. Belo Horizonte, MG/Brasil. rsnatorres@gmail.com

\section{[II] https://orcid.org/0000-0002-4298-455X}

Universidade Federal de Minas Gerais, Faculdade de Ciências Econômicas, Centro de Desenvolvimento e Planejamento Regional. Belo Horizonte, MG/Brasil. joaotonucci@cedeplar.ufmg.br

\section{[III] https://orcid.org/0000-0003-1741-7665}

Universidade Federal de São João del-Rei, Departamento de Ciências Econômicas, Programa de Pós-Graduação em Desenvolvimento, Planejamento e Território. São João del-Rei, MG/Brasil. renan@ufsj.edu.br 


\section{Nota de agradecimento}

Parte deste texto tem origem na dissertação de mestrado "O circuito financeiro imobiliário no Brasil: aspectos recentes do processo de financeirização", de Ramon da Silva Torres, defendida em 2021 no Programa de Pós-Graduação em Economia do Cedeplar/Face/UFMG, sob orientação do professor João B. M. Tonucci Filho. Os autores agradecem ao auxílio financeiro da Capes e aos membros da banca final e pareceristas anônimos deste trabalho pelos comentários e recomendações.

\section{Notas}

(1) Atualmente, há dois focos de estudos sobre os CRIs e os Flls no País: uma linha mais pragmática, cujo epicentro pode ser considerado o Núcleo de Real Estate dentro do departamento de Engenharia e Construção Civil da Escola Politécnica da USP; e outro, mais recente, baseado na literatura internacional e nacional sobre a financeirização do imobiliário, no campo dos estudos urbanos e da geografia econômica, através das contribuições de Sanfelici e Halbert (2018), que analisam o processo de criação dos Flls e o papel desempenhado pelo Estado; Melazzo e Abreu (2019), que exploram a securitização imobiliária em Ribeirão Preto/SP; Abreu (2019), ao especializar os imóveis lastros de uma das maiores emissões de CRI no País, ressaltando a heterogeneidade espacial de um ativo homogêneo; e Franco (2019), ao analisar as regras tributárias aplicáveis aos Flls e seus padrões de distribuição territorial, em especial nas principais metrópoles do País.

(2) O FIl é uma formatação jurídica que permite a comunhão de recursos de inúmeros investidores através da compra de cotas, frações ideais do patrimônio do fundo, e cujos valores são aplicados exclusivamente no mercado imobiliário. Os Flls podem investir diretamente em imóveis, em dívidas com lastro imobiliário ( $\mathrm{CRI}, \mathrm{LCl}$, debêntures) ou mesmo em ações de empresas que atuam no ramo imobiliário.

(3) O Sistema Financeiro da Habitação (SFH) foi criado em 1964 com o objetivo de desenvolver o crédito habitacional e imobiliário no Brasil. O funding do sistema era proveniente dos recursos do FGTS e das cadernetas de poupança das entidades vinculadas ao Sistema Brasileiro de Poupança e Empréstimo (SBPE). Ao longo de sua história, o SFH passou por diversos arranjos e, atualmente, é regulado pelo Conselho Monetário Nacional (CMN), órgão vinculado ao Banco Central (Bacen) e regido pela instrução CMN n. 4.676, de 31 de julho de 2018.

(4) No regime de alienação fiduciária, é transferida apenas a posse do imóvel ao mutuário, enquanto o domínio ou a propriedade permanece atrelada ao credor até que se quite o financiamento imobiliário. No regime de hipotecas, a posse e o domínio são transferidos ao mutuário. Além disso, a execução da garantia real, ou seja, a retomada do imóvel em caso de inadimplência é mais célere através da alienação fiduciária, uma vez que todo o processo transcorre via cartório sem necessidade de judicialização. 
(5) Fix (2011) destacou o papel do investimento internacional na participação das companhias securitizadoras através dos mesmos fundos que realizaram aporte de capital em outras empresas do ramo imobiliário, como Gafisa, Bracor, BRMalls e AGV, demonstrando que, ao menos até aquele momento, havia participação relevante do capital internacional na construção da securitização imobiliária no Brasil.

(6) Webscraping ou data mining é uma prática de automação de coleta de dados em páginas da Internet, na qual é construído um código para consultar um servidor web, requisitar informações (geralmente em formato HTML), extraí-las, parser os dados, ou seja, organizá-los em uma estrutura lógica para posterior armazenamento e análise. Construiu-se um algoritmo em Python para webscraping dos dados na plataforma de consulta sobre os CRIs, sistematizando as informações de cada CRI por linha em um arquivo csv. Ao todo, foram captadas informações sobre 1635 séries de CRI distribuídas em 1226 ofertas. O código do algoritmo, assim como as instruções para extração de dados, está disponível em um repositório no GitHub.

(7) https://www.anbima.com.br/pt_br/informar/dados-de-emissao-de-cri.htm. Acesso em: 10 ago 2021.

(8) Foram utilizadas as seguintes palavras-chave para agrupamento dos agentes: (1) Bancos: Banco; (2) Companhias Hipotecárias: Companhia Hipotecária, Cia. Hipotecária; hipotecária; (3) Fundos de Investimento Imobiliários: Fundo de Investimento Imobiliário, FII; (4) Empresas Imobiliárias: SPE, Empreendimentos Imobiliários, Empreendimentos, Empreendimento, Incorporação, Urbanizadoras, Participações, Properties, Administradora, Shopping; e (5) Outros: caso não houvesse nenhuma das palavras-chave anteriores na razão social.

(9) Sendo a maior parte emitida pelas Government Sponsored Enterprises (GSE). A securitização residencial está atrelada aos Residential Mortgage Backed Securities (RMBS), enquanto a corporativa está formatada sobre os Commercial Mortgage Backed Securities (CMBS).

(10) Nas palavras de um dos conselheiros do CCFGTS, conforme registrado em ata da reunião ordinária n. 152, de 10 de maio de 2016.

(11) Esse fluxo de caixa positivo que o fundo obtém a partir de suas diversas aplicações é um dos elementos que contribuem para o que Royer (2009) ressalta como a "robustez financeira" do FGTS.

(12) Segundo dados do Relatório 4010 do Banco Central, excetuando-se as aplicações de recursos do FGTS.

(13) Disponível em: https://www.correiobraziliense.com.br/app/noticia/economia/2019/01/07/ internas_economia,729394/caixa-pretende-vender-ate-r-100-bi-em-securitizacao-de-creditoimobil.shtml. Acesso em: 26 jan 2021.

(14) Disponível em: https://economia.uol.com.br/noticias/estadao-conteudo/2020/08/11/ caixaguimaraes-fizemos-a-securitizacao-em-ipca-e-ja-estamos-em-r-10-bilhoes.htm. Acesso em: 26 jan 2021. 


\section{Referências}

AALBERS, M. B. (2008). The financialization of home and the mortgage market crisis. Competition \& Change, v. 12, n. 2, pp. 148-166.

(2016). The financialization of housing: a political economy approach. Londres, Routledge.

(2017). The variegated financialization of housing. International Journal of Urban and Regional Research, v. 41, n. 4, pp. 542-554.

ABRAMO, P. (2007). A cidade caleidoscópica: coordenação espacial e convenção urbana: uma perspectiva heterodoxa para a economia urbana. Rio de Janeiro, Bertrand Brasil.

ABREU, M. (2019). “O mercado habitacional confiscado pelas finanças: uma análise a partir dos Certificados de Recebíveis Imobiliários”. In: SHIMBO, L.; RUFINO, B. (orgs.). Financeirização e estudos urbanos na América Latina. Rio de Janeiro, Letra Capital.

ANBIMA (2014). Fundos de investimento imobiliário. Rio de Janeiro, Anbima.

BOGUS, L.; RIBEIRO, L. C. de Q. (2018). Apresentação. Cadernos Metrópole. São Paulo, v. 20, n. 43, pp. 613-623.

BRETT, B. (2016). From performativity to political economy: index investing, ETFs and asset manager capitalism. New Political Economy, v. 21, n. 3, pp. 257-273.

COLES, A.; HARDT, J. (2000). Mortgage markets: why US and EU markets are so different? Housing Studies, v. 15, n. 5, pp. 775-783.

CROTTY, J. (2008). If financial market competition is intense, why are financial firm profits so high? Reflections on the current 'golden age' of finance. Competition \& Change, v. 12, n. 2, pp. 167-183.

DEFUSCO, A. et al. (2018). The role of price spillovers in the American housing boom. Journal of Urban Economics, v. 108, pp. 72-84.

DYMSKI, G. A. (2009). Why the subprime crisis is diferente: a Minskyian approach. Cambridge Journal of Economics, v. 34, pp. 239-255.

FIX, M. (2011). Financeirização e transformações recentes no circuito imobiliário no Brasil. Tese de doutorado. Campinas, Universidade Estadual de Campinas.

FRANCO, F. (2019). Dimensões territoriais da isenção tributária dos Fundos de Investimento Imobiliário no Brasil. Dissertação de mestrado. São Paulo, Fundação Getúlio Vargas.

GOTHAM, K. F. (2012). "Creating liquidity out of spatial fixity: the secondary circuit of capital and the restructuring of the US housing finance system". In: AALBERS, M. (org.). Subprime cities: the political economy of mortgage markets. Oxford, Oxford University Press.

HAILA, A. (1988). Land as a financial asset: the theory of urban rent as a mirror of economic transformation. Antipode, v. 20, n. 2, pp. 79-101.

HARVEY, D. (2006). The limits to capital. Londres/Nova York, Verso.

(2007). A brief history of neoliberalism. Oxford, Oxford University Press.

(2012). "Foreword: the urban roots of the financial crisis". In: AALBERS, M. (org). Subprime cities: the political economy of mortgage markets. Oxford, Oxford University Press. 
JORDÀ, O. et al. (2014). The great mortgaging: housing finance, crisis, and business cycles. NBER Working Paper, n. 20501.

LEVELS, A.; CAPEL, J. (2012). Is colateral becoming scarce? Journal Of Financial Market Infrastructures, v. 1 , n. 1, pp. 29-53.

LOFTUS, A. et al. (2018). The political economy of water infrastructure: an introduction to financialization. Wiley Interdisciplinary Reviews Water, v. 6, n. 1, pp. 13-26.

MELAZZO, E. S. E.; ABREU, M. A. (2019). A expansão da securitização imobiliária. Uma prospecção a partir da cidade de Ribeirão Preto/SP. Espaço e Tempo, v. 23, n. 1, pp. 22-39.

PAULANI, L. (2016). Acumulação e rentismo: resgatando a teoria da renda de Marx para pensar o capitalismo contemporâneo. Revista de Economia Política, v. 36, n. 3, pp. 514-535.

PECK, J. (2014). Pushing austerity: state failure, municipal bankruptcy and the crises of fiscal federalism in the USA. Cambridge Journal of Regions, Economy and Society, v. 7, n. 1, pp. 17-44.

PEREIRA, A. (2015). Intervenções em centros urbanos e conflitos distributivos: modelos regulatórios, circuitos de valorização e estratégias discursivas. Tese de doutorado. São Paulo, Universidade de São Paulo.

(2017). Financialization of housing in Brazil: New frontiers. International Journal of Urban and Regional Research, v. 41, n. 4, pp. 604-622.

PIKETTY, T. (2014). O capital no século XXI. Rio de Janeiro, Intrínseca.

ROLNIK, R. (2015). Guerra dos lugares: a colonização da terra e da moradia na era das finanças. São Paulo, Boitempo.

ROYER, L. (2009). Financeirização da política habitacional: limites e perspectivas. São Paulo, Universidade de São Paulo.

(2016). O FGTS e o mercado de títulos de base imobiliária: relações e tendências. Cadernos Metrópole. São Paulo, v. 18, n. 35, pp. 33-52.

RYAN-COLLINS, J. et al. (2017). Rethinking the economics of land and housing. Londres, Zed Books.

SANFELICI, D. (2013). A metrópole sob o ritmo das finanças: implicações socioespaciais da expansão imobiliária no Brasil. Tese de doutorado. São Paulo, Universidade de São Paulo.

SANFELICI, D.; HALBERT, L. (2018). Financial market actors as urban policy-makers: the case of real estate investment trusts in Brazil. Urban Geography, v. 40, n. 1, pp. 83-103.

SANTORO, P.; ROLNIK, R. (2017). Novas frentes de expansão do complexo imobiliário-financeiro em São Paulo. Cadernos Metrópole. São Paulo, v. 19, n. 39, pp. 407-431.

SASSEN, S. (2020). Expulsões: brutalidade e complexidade na economia global. Rio de Janeiro/São Paulo, Paz e Terra.

SCHWARTZ, H. (2012). "Finance and the state in the housing bubble". In: AALBERS, M. (org). Subprime cities: the political economy of mortgage markets. Oxford, Oxford University Press.

SHIMBO, L. (2010). Habitação social, habitação de mercado: a confluência entre Estado, empresas construtoras e capital financeiro. Tese de doutorado. São Paulo, Universidade de São Paulo.

THEODORE, N. (2019). Governing through austerity: (I)logics of neoliberal urbanism after the global financial crisis. Journal of Urban Affairs, v. 42, n. 1, pp. 1-17. 
TONUCCI, J.; MAGALHÃES, F. (2017). A metrópole entre o neoliberalismo e o comum: disputas e alternativas na produção contemporânea do espaço. Cadernos Metrópole. São Paulo, v. 19, n. 39, pp. 433-454.

UQBAR (2019). Fundos de Investimento Imobiliário. Disponível em: https://www.uqbar.com.br/ anuarios-2019-patrocinadores/. Acesso em: 2 ago 2021.

(2020). Fundos de Investimento Imobiliário. Disponível em: https://www.uqbar.com.br/ anuario-fundo-de-investimento-imobiliario-2020/. Acesso em: 2 ago 2021.

ZHANG, H. et al. (2016). Comparisons of the relations between housing prices and the macroeconomy in China's first-, second- and third-tier cities. Habitat International, v. 57, pp. 24-42.

Texto recebido em 31/mar/2021

Texto aprovado em 22/jun/2021 